\&9.13.6". The Librarian to the Medical Society of London agreed to take on the administrative duties connected with the Association's book collection for an annual fee of $£ 10$. At the Annual meeting of 1896 Dr Rayner was able to report that all the gifts from Mrs Tuke had been catalogued and arranged in the Association's "room for its use" - the first reference to library accommodation. At this meeting $\mathrm{Dr}$ Rayner also acknowledged Dr F. Hay of Perth who made a unique contribution to the collection by designing an unusual commemorative book plate. It features a feather motif on a bronze background.

Financial matters are the main feature of Library Committee reports of the following years with requests for small but increasing sums of money to cover administration and accommodation rather than the purchase of books. In 1897 the Hack Tuke Memorial Committee made its approval apparent by agreeing to "hand over to the MPA the sum of $£ 350$ to be vested in trustees, the annual income derived therefrom to be expended in maintaining and increasing the library, of which Dr Hack Tuke's gift to the Association has proved such a valuable nucleus". This capital was later invested in New Zealand Stock, maturing in 1940 and was probably reinvested in war bonds.
By the turn of the century the Library was well established. Other donations of books were received, with those of past Presidents Dr C. Lockhart Robertson and Dr J. C. Bucknill of particular note.

In November 1899 Dr Fletcher Beach, Secretary of the Library Committee, informed Council that a catalogue of books held in the Library had been "printed and issued to every member of the Association". The aim of the Committee that all members should have access to the Library was thus achieved.

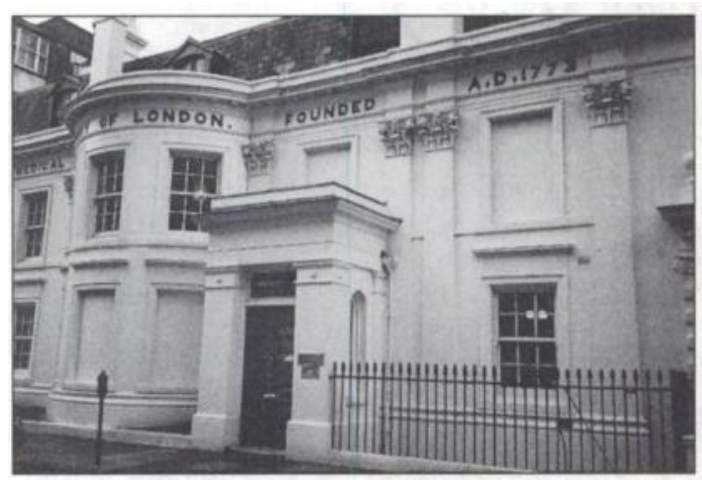

The Medical Soclety of London.

\title{
Health of the Nation and the medical profession
}

Members of the College will have received an information pack from the Department of Health, entitled The Health of the Nation what you can do about it. This documentation has been produced by a working group of hospital doctors which was set up by the Chief Medical Officer, to look at ways of promulgating the health messages contained in the Health of the Nation, and to produce brief, clear guidance for hospital doctors on achieving the targets in the key areas outside their individual specialities.

The Department of Health has circulated to all consultants, senior registrars, and other doctors, a brochure suggesting methods of facilitating health promotion in each of the five Health of the Nation key areas. A concise, pocket-sized leaflet has been circulated to junior doctors. In both cases, actions are listed which it is considered that hospital doctors could usefully take to further the Health of the Nation.

The Chief Medical Officer, in his introductory letter, recognises the enormous time constraints under which hospital doctors work but emphasises that doctors have a great deal of influence in getting patients to change their lifestyle.

The Executive and Finance Committee of the College wishes to encourage members of the profession to work towards the Health of the Nation targets in the ways suggested.

Dr F. CALdicotT, President, Royal College of Psychiatrists 